\title{
CODE SWITCHING AS INTERLANGUAGE COMMUNICATION STRATEGY BY INDONESIAN EFL LEARNERS
}

Alih Kode Sebagai Strategi Komunikasi Bahasa Antar Pembelajar Bahasa Inggris di Indonesia

\author{
Endang Fauziati ${ }^{1}$, Hartati Widiastuti², dan Hanif Maghfur Darussalam ${ }^{3}$ \\ 1,2,3 Universitas Muhammadiyah Surakarta \\ endang.fauziati@ums.ac.id
}

Naskah Diterima Tanggal 2 Februari 2020_-Direvisi Akhir Tanggal 21 Oktober 2020_Disetujui Tanggal 24 November 2020 doi: https://doi.org/10.26499/rnh.v9i2.2950

\begin{abstract}
Abstrak
Penelitian ini bertujuan untuk mengeksplorasi penggunaan alih kode sebagai strategi komunikasi bahasa antar pembelajar bahasa Inggris di Indonesia. Secara khusus, penelitian ini bertujuan untuk mendeskripsikan pola alih kode dan faktor yang berkontribusi pada penggunaan alih kode tersebut sebagai strategi komunikasi oleh pembelajar bahasa Inggris. Jenis penelitian ini adalah kualitatif dengan subjek penelitian 30 siswa dari salah satu SMP di Surakarta. Pengumpulan data dilakukan dengan teknik elisitasi, yang dilakukan dengan memberikan tugas kepada subjek penelitian untuk mendeskripsikan sebuah kartun. Ucapan mereka direkam dan digunakan sebagai sumber data primer. Ucapan yang mengandung alih kode diidentifikasi dan digunakan sebagai data primer. Data dianalisis secara kualitatif dengan teknik induktif yang menggunakan kerangka analisis Dornyei \& Myers-Scotton. Temuan penelitian kemudian diinterpretasikan berdasarkan teori yang relevan. Hasil penelitian menunjukkan bahwa siswa menggunakan tiga jenis alih kode, yaitu alih kode tag, alih kode intrasentensial, dan alih kode antarsentensial. Tiga faktor yang berkontribusi terhadap penggunaan alih kode tersebut adalah kedwibahasaan, penguasaan bahasa Inggris yang terbatas, dan sebagai strategi kompensasi. Dapat disimpulkan bahwa penggunaan alih kode oleh pembelajar bahasa Inggris merupakan fenomena alami dan tidak dapat dihindari dalam pembelajaran bahasa Inggris sebagai bahasa asing. Hal ini merupakan salah satu strategi komunikasi untuk mengompensasi keterbatasan penguasaan bahasa sasaran.
\end{abstract}

Kata-kata kunci: alih kode, strategi komunikasi, strategi kompensasi, bahasa asing

\begin{abstract}
This study was aimed at exploring the use of code switching (CS) as interlanguage communication strategy by EFL students when they were communicating in English. Particularly, this study tried to describe the patterns of $\mathrm{CS}$ as communication strategy and factors that contributed to the use of the CS as communication strategy by the EFL learners. It was a qualitative research using 30 students of one of Junior High School in Surakarta as research subjects. The data were collected through elicitation technique in which the research subjects were given a task to describe a cartoon. Their utterances were recorded and used as primary data source. Utterances that contained CS were identified and used as primary data. The data were analyzed qualitatively by inductive techniques, using Dornyei and Myers-Scotton analysis frameworks. The research findings were then interpreted based on relevant theory. The results showed that the students used three types of CS, namely tag code switching, intra-sentential code switching and inter-sentential code switching. Three factors identified as the reasons of the use of CS as communication strategy were bilingual, limited mastery of English and as a compensation strategy. It can be concluded that the use of CS by EFL learners is a natural and unavoidable phenomenon since this represents one of the communication strategies to compensate for the EFL learners' limited mastery of the target language they are learning.
\end{abstract}

Keywords: code switching, communication strategy, compensation strategy, EFL

How to Cite: Fauziati, Endang, Hartati Widiastuti dan Hanif Maghfur Darussalam. (2020). Code Switching as Interlanguage Communication Strategy by Indonesian EFL Learners. Ranah: Jurnal Kajian Bahasa. 9(2). 301-311. doi: https://doi.org/10.26499/rnh.v9i2.2950 


\section{INTRODUCTION}

The main objective of learning English as a foreign language is to be able to communicate. Through communication, people send and receive messages effectively as well as negotiate meaning or messages (Rubin \& Thompson, 1994). Learning English in the current era emphasizes the ability to communicate effectively and this becomes far more important than the ability to read and write. Thus, the communication strategy has become an important topic for EFL learners and instructors.

Communicative strategy is basically an effort made by EFL learners as a stratagem to avoid linguistic difficulties or to compensate their inability to communicate with listeners or interlocutors. Such strategies are generally used by EFL students when their limited knowledge makes it difficult for them to express the intended message. Selinker (1977) introduced the term communication strategy or second language communication strategy to refer to one of the five processes which are responsible for production of interlanguage errors by EFL learners. Meanwhile, Tarone (1981) described the communication strategy as a systematic effort by the learner to express and interpret messages in the target language. Therefore, communication strategies can function to compensate the inability of speakers and listeners in the target language being learned.

Communication strategies are commonly discussed as one of the categorizations of language learning strategies. EFL learners are often observed using certain strategies to communicate when their target language knowledge is not sufficient. One of the strategies is how to make themselves understood when using English as the second or foreign language. They use communication strategies to compensate for their deficiencies in grammar as well as vocabulary. Communication strategies can help them to participate in and to maintain conversation as well as to improve communication quality. In turn, this will allow them to increase the exposure and the opportunities to use the target language. Without such strategies, learners tend to avoid taking the risk of using the target language by avoiding certain topics or a conversation situation.

A strategic competence in communication is very crucial and widely recognized in EFL learning since Oxford (2003) included it as one of the components in the construction of communicative competence concept. In this case, a strategic competence refers to a competency of verbal and non-verbal communication that can improve communication efficiency and enables learners to overcome their difficulties when communication breakdowns occur. Dornyei \& Scott (1997) also cited by Brown (2000) classify 
communication strategies into two branches that reveal two differing directions in communication, that is, to avoid and to give compensation. Furthermore, avoidance strategies may include several sub-types of strategy such as phonological avoidance, syntactic or lexical avoidance and topic avoidance (Brown, 2000). Meanwhile, compensation strategies involve "compensation for lack of knowledge" (Brown, 2000). Dornyei elaborated eleven types of compensation strategies, including circulation, said coins, prefabricated patterns, asking for help and buying time or strategies for getting time. And compensation strategy includes code switching.

Code switching or alternating use of two languages or codes in constituencies, sentences or discourse is a common phenomenon in society (Poplack, 1980; Schmidt, 2014). Code switching can be found in every communication event, including in foreign language classes (Moore, 2010). Poplack (1980) proposes three types of code switching, namely tag-switching, intra-sentential switching and inter-sentential switching. Tag-switching refers to the insertion of a tag (brackets, an exclamation, filler sentence or idiomatic expression) in one language into a sentence in other languages, for example "you know", "I mean" and "right." Intrasentential switching requires space in sentences while inter-sentential switching is between sentences, where space is needed between sentences in which each sentence is in different languages.

Several related research have been carried out previously. Chung (2026) conducted a study of CS as a communication strategy by Korean-English bilinguals. The qualitative data analysis indicated that CS used was shaped by the dynamic relationship of the speakeraddressee. CS functioned as a communicative strategy to facilitate family communication by lowering language barriers. Meanwhile, Grainger (2010) conducted a study on communication strategies used by English language learners as a foreign language based on their level of English competence. The results of statistical analysis showed that the learners used communication strategies to be able to communicate smoothly (to maintain communication in spoken interactive contexts). The types and patterns of strategies they used were positively correlated with English competence. There were some differences in the use of communication strategies of learners with high, medium and low English competence. These differences were directly related to the intention to code switching to their mother tongue to solve the communication problems.

Metcalfe \& Ura (2013) examined the communication strategies used by first-year students of Chulalongkorn University. The results showed that the communication strategy 
patterns most frequently used were message reduction and alteration, non-verbal strategies, social-affective and negotiation for meaning. Whereas the least used strategy was message abandonment. The results also showed that there was a positive correlation between the use of communication strategies and students' English competence. Students with high competence were more likely to take advantage of achievement strategies, especially social-affective, fluency-oriented, negotiation for meaning and circumlocution. While students with low competency utilized reduction strategies, especially message abandonment and less active listener.

Andayani (2014) investigated the CS as communication strategy used by Indonesian EFL students in the classroom settings. The findings indicated that the students used all three types of code-switching, especially the word type, followed by phrase and sentence. They used CS in order to feel comfortable and get some help while studying English. Finally, Nyambura (2015) who conducted a study on code switching argued that CS is really an effective communication strategy for both students and teachers since CS could help them address their various needs. CS could also facilitate interpersonal communication and overcome communication difficulties. This study posited that, pedagogically, CS is a very useful communicative resource, an effective tool to ease communication between teachers and students. Therefore, teaching and learning process becomes much easier and enjoyable and enable both the teachers and learners to express themselves freely in class.

A comprehensive study on CS as a communication strategy by EFL learners in Indonesian context was very significant. A comprehensive description on this issue provides an explanation of the process of producing oral English by Indonesian learners. And the results of this study may enrich the theory of second language acquisition by Indonesian learning, especially CS as communication strategy. The current study was intended as complement to the previous ones, as it specifically tried to uncover the model of CS as communication strategy by Indonesian EFL learners. In addition, it tried to uncover possible factors that contribute to the use of CS as communication strategy.

\section{RESEARCH METHODS}

This research used a qualitative approach (Ellis, 2006) commonly used in research of second language acquisition in the classroom context. Ellis (2006) called it instructed second language acquisition. This qualitative method aims to produce a hypothesis that is done 
inductively, that is, by collecting data in various ways, then conclusions are drawn as assumptions that explain the data.

The subjects in this study were students of one of Junior High Schools in Surakarta. The research subjects were 40 students. All students are Indonesian and Javanese bilingual and have studied English for about three years through formal education in junior high school. The subjects are homogeneous in terms of citizenship, language background, level of education, level of English language proficiency and age.

The primary data were utterances containing CS as communication strategy collected from oral production made by students. Secondary data were in the form of information about the foreign language speech production process, how learners used CS as communication strategy to maintain communication smoothly. This information was needed to explain the factors that contribute to the use of CS. Data validity was done by member checking, triangulation and inter-coder reliability.

The data collection techniques used in this study were interview and cartoon description English speaking tasks to elicit students to produce speech and utilize CS as communication strategy in the speaking process (Dornyei, 1995). The data collected were analyzed qualitatively by describing data quotations in the form of transcripts of students' speaking tasks. The taxonomy proposed by Dornyie was used to analyze and identify each CS strategy used by the students. Qualitative analysis or inductive approach was used to analyze qualitative data in order to describe and explain the factors which contribute to the use of CS as communication strategy (Thomas, 2006).

\section{RESULT}

This section presents the results of the research presented in the introduction, which include: (1) patterns of CS as communication strategy used by English learners and (2) factors that contribute to the use of CS as communication strategy used by English learners.

\section{Pattern of CS as Communication Strategy Used by the EFL Learners}

The pattern of CS as communication strategy was analyzed using the Poplack's (1980) framework. The results showed that CS or alternating use of two languages or codes in constituencies, sentences or discourse used by the EFL learners under this study consisted of three types, namely tag-switching, intra-sentential switching and inter-sentential switching. 


\section{a. Tag-Switching}

The tag switching was realized by inserting a tag (tail of the sentence) in Indonesian, becoming part of a sentence in English. Some Indonesian tag words found in the data were apa tuh, tuh, apa, apa ya, ya, yah, anu, gitu, gitu, atau gitu lho. For example, when telling about their parents, a student stated "My mother doesn't work; she is ...eee eee em apa tuh... ibu rumah tangga eeemm a house wife". Initially, he stated the Indonesian word ibu rumah tangga, then followed by tag apa tuh while thinking of its equivalent in English and eventually found the word house wife.

When mentioning the tag word apa tuh, his eyes suggested that he was trying to find out the appropriate English vocabulary to convey the intended idea. Commonly, the students used tag switching in order to maintain communication. With this tag inserted, they hoped that a friend or the teacher would help them to find the right vocabulary. So, they used tag switching from English to Indonesian as a communication strategy when they had difficulty in finding the right vocabulary. Here are some other examples taken from the data.

(1) I like my friends in school because we play together help eee.... each other ... gitu ya.

(2) I like study here Eee... because..... eeee.....the teacher is friendly... ya...friendly.

(3) My sister... study in UNS; she is very....... ee .... anu she is very intellectual.

(4) I proud my brother because he is smart about mathematic gitu.

(5) The people in my town like emmm ...kerja bakti... eehmm wotk together gitu loh.

\section{b. Intra-Sentential Switching}

The results showed that the EFL learners employed intra-sentential code switching as a communication strategy. In this case, intra-sentential code switching is a transition from English to Indonesian that occurs in a sentence and the code switching involves syntactic units of words, phrases or clauses. This commonly occurred when the students got problem with English vocabulary, as seen in the examples below.

(1) After SMA school I want get eemmm beasiswa to university.t

(2) He was not interested in girls around me or penasaran to know a woman.

(3) I start berlatih.... eehmm practice breakdance from class five elementary school.

(4) I like listen K-pop music but I don't understand ehhmm lirik lagunya...gitu..

(5) In our extra-curricular activities I join traditional dancing and karawitan.

\section{c. Inter-Sentential Switching}

Code switching is categorized as inter-sentential code switching when it occurs beyond sentences. The data indicated that the students used inter-sentential switching from English to Indonesian or the vice versa in a complete clause or sentence. In this case, Indonesian acted as the insertion language. while English as the matrix language. In the following data, the form of inter-sentential code switching is in the form of insertion of an Indonesian language clause 
that is underlined. For example, a student uttered "My brother work in Bank Indonesia Surakarta. He is ehhm satpam.... eehm sorry tidak tahu bahasa Inggrisnya satpam". In this example, the clause "tidak tahu bahasa Inggrisnya satpam" was inserted in his English sentence. This is categorized as inter-sentential switching as the utterance already contains elements of the subject and predicate that is still in the main sentence. The data above shows that the student used English as a matrix language and Indonesian as an insertion language. Here are some other examples found in the data.

(1) Ehmm I like my English teacher because she is clever...and kalau menjelaskan itu enak gitu Iho and I understand.

(2) I want to study engineering in UNS because I like to design home, but I ... ehmm belum begitu bisa komputer.

(3) But.. I am sorry I don't like Biology teacher because he is membosankan dan tidak humoris... ehmm ... I am so boring.

(4) I like teacher sport because he is handsome.. eehmm seperti Suju K-Pop dan suka eehmm... anu bercanda.. apa ya... joking.

\section{Factors Contributing to the Use of a CS as Communication Strategy}

The results of analysis indicated three factors that could contribute to the existing phenomenon of CS as a communication strategy in the EFL class under this study. These three factors are bilingual or bilingual mastery, limited mastery of English and as a compensation strategy.

\section{a. Bilingual or Bilingual Mastery}

The English learners in this study had a good ability to use two languages, namely Indonesian and Javanese, and speak a little English. This condition is referred to as bilingual. In the English class, of course, they were required to convey their ideas in English. In this case, it can be said that the English learners under this study were bilingual who experienced bilingualism in the classroom. Bilingual or bilingualism refers to the use of two or more languages by a person or a community (Kridalaksana, 2008). The learners experienced discrimination in their English class when English and Indonesian are used interchangeably and occur in a specific speech event. In this research, the speech event was a story telling on the basis of a cartoon in English.

This bilingual situation occurs due to contact of the two languages (Bloomfield in Chaer \& Agustina, 2010), namely English and Indonesian. Bilingual learners here mean mastering the two language systems in their minds. Both linguistic systems are interdependent and support each other. That is, when the English learners expressed their ideas in English and experience difficulties, their mind automatically utilized the Indonesian language system that 
was ready to use. This was intended so that the English communication run well. It is inevitable that a bilingual speaker uses one language absolutely without using any other language or the other language elements. In this case, the students used English as a matrix, while Indonesian as a tool or compensation strategy when they experienced difficulty in using English.

\section{b. Limitations of English Language Mastery}

Another factor that contributes to the use of CS as communication strategy is the target language linguistic factor. The EFL learners under this study was at the Junior High School and had limited mastery of English. Code switching from English to Indonesian could not be avoided cognitively. In a condition where they had to express their ideas in English, but were constrained by the limited ability of the target language, they automatically tried to find the source of language system already available in their cognitive construction. And the language system readily available for use was their mother tongue (Indonesian). It was clear that because of their limitations in the language abilities of the target language, the learners utilized CS as the compensation communication strategy. This is a conscious effort in verbal mechanisms to communicate ideas when linguistic forms are not available in the minds of learners.

The level of linguistic abilities for the target language learners can be seen from their mastery of grammatical, lexical, semantic and pragmatic aspects that are reflected when communicating. The better the mastery of these linguistic aspects, the better the level of bilingualism will be. Preferably, the lower the mastery of these linguistic aspects, the lower the level of bilingualism. One of the signs of this condition is the use of code switching strategy.

\section{c. Code Switching as a Compensation Strategy}

The last factor that could be identified as to contribute to the use of CS as communication strategy by the learners is the compensation strategy for the limited mastery of the target language. The use of this compensation strategy specifically aimed to assist the students in maintaining communication in the target language. It also aimed to compensate for the limitations in the vocabulary and grammar of the target language. Moreover, when the learners were experiencing communication breakdown in the target language, they consciously tried to find solutions to these problems, regardless of their lack of linguistic knowledge. The results of observation showed that by using CS as compensation strategy, 
they seemed more confidence to express their ideas in English and they tried well to accomplish the tasks.

\section{DISCUSSION}

\section{Types of Code Transfer Communication Strategies by English Learners}

The results of analysis showed that there are three types of CS as communication strategies used by English learners in this study, namely tag-switching, intra-sentential switching and inter-sentential switching. The results of this study are in line with Andayani's (2014) findings as well as the theory conveyed by Poplack (1980). In other words, the three codes of communication strategy models are all used by English learners as a foreign language. Along with Poplack, Dörnyei (1995) identified a variety of communication strategies, one of which is code switching which functions as a compensation strategy for mastering limited language of the target language. He further argued that communication strategies can ultimately increase communication effectiveness.

The results of this study are also in line with the results of Grainger's (2010) study that English learners use code switching to reflect their level of English competence. Learners mainly use communication strategies to be able to communicate, to maintain communication in the target language. This is supported by research findings of Chung (2006), Grainger (2010), Metcalfe \& Ura (2013) and Nyambura's (2015) that learners can maintain communication in English by using various communication strategies, including code switching. Utilization of this communication strategy also shows students' English competence.

From the phenomenon above, the researchers hypothesize that the use of CS as communication strategies by EFL learners is cognitively common and cannot be avoided. The main purpose of using code switching is to be able to communicate, even with limited target language competence, both in grammatical and vocabulary aspects.

\section{Factors Contributing to the Use of a CS as Communication Strategy by EFL Learners}

The results showed there were three factors that contributed to the phenomenon of code switching as a communication strategy in the English class as a foreign language, namely mastery of two languages or bilingual, limitations in mastering English and as a compensation strategy. These conditions can be explained by Grosjean's (2008) bilingual concept, that is bilingual has two linguistic systems in their mind. In this case, the learners have at least two 
language systems, Indonesian and English language systems. As an Indonesian students, they usually have one-language mode, namely Indonesian. They communicate in Indonesian. That is, they activate the Indonesian language system. However, in a particular speech event, English class, they communicate with English teachers in English. They try to activate the English language system that they are learning. They must consciously non-activate Indonesian.

Bilinguals commonly communicate differently when they communicate with monolingual and with bilingual who shares their language. In this case, the learners communicate differently when they are with their friends and with their English teachers. Similar to previous phenomenon, it can be hypothesized that the use of CS as communication strategy by EFL learners is cognitively common and cannot be avoided, and that the main purpose of using CS switching is to be able to maintain communication even with limited target language competence, both in grammatical and vocabulary aspects.

\section{CLOSING}

This study aimed to disclose the use of CS as communication strategy by the Indonesian EFL learners when they communicate in English. The analysis showed that all three types of code switching - tag code switching, intra-sentential code switching and inter-sentential code switching are used by the EFL learners. The factors that contribute to the use of CS as a communication strategy in the EFL class are the knowledge of two languages or bilingual, limited mastery of English and CS as a compensation strategy. Based on the findings, it can be concluded that the use of CS by Indonesian EFL is a natural and unavoidable phenomenon because CS functions as a communication strategy, especially to compensate for the limited linguistic mastery of the target language.

\section{BLIBLIOGHRAPY}

Andayani, T. (2014). Code-switching, a communication strategy in learning English. Proceedings of the ISELT-4. ejournal.unp.ac.id > index.php > selt > article > download

Appel, R., \& Muysken, P. (2006). Language Contact and Bilingualism. Amsterdam University Press: Amsterdam. https://doi.org/10.5117/9053568573

Brown, H. D. (2000). Principles of language learning and teaching (4th Ed.). New York: Addison Wesley Longman, Inc.

Canale, M \& Swain, M. (1980). Theoretical bases of communicative approaches to second language teaching and testing. Applied Linguistics, 1, 1-47. https://doi.org/10.1093/applin/1.1.1

Celce-Murcia, M. (ed.) (1995). Teaching English as a second or foreign language (2nd ed.). Boston, Massachusetts: Heinle \& Heinle Publishers. 
Chung, H. H. (2006). Code switching as a communicative strategy: A case study of Korean-English bilinguals. Bilingual Research Journal .30(2), 293-307. https://doi.org/10.1080/15235882.2006.10162878

Dornyei, Z., \& Scott, M. L. (1997). Communication strategies in a second language definitions and taxonomies. Language Learning. 47, 173-210. https://doi.org/10.1111/0023-8333.51997005

Ellis, R. (2006). The study of second language acquisition. Oxford, England: Oxford University Press.

Grainger, P. R. (2010). Spoken communication strategies used by learners of Japanese in a foreign language learning environment. Unpublished Thesis, University of Queensland, Australia. Retrieved from https://www.researchgate.net/publication/277013435_

Grosjean, F. (2008). Studying bilinguals. Oxford, England: Oxford University Press.

Hoffman, Ch. (1991). An Introduction to bilingualism. London: Longman

Lai, H. (2010).Gender effect on the use of CSs. ELT English Language Teaching. 3(4), 28-32. https://doi.org/10.5539/elt.v3n4p28

Myers-Scotton, C. (1993). Social motivations for code switching. Evidence from Africa. Oxford: Clarendon Press.

Metcalfe, J. \& Ura, S. N. (2013). Communication strategy use of high and low proficiency learners of English at a Thai University. LEARN Journal. 6(1), 68-89.

Moore, D. (2010) Code-switching and learning in the classroom. International Journal of Bilingual Education and Bilingualism 5(5), 279-293. https://doi.org/10.1080/13670050208667762

Muysken, Pieter (2000): Bilingual Speech. A Typology of Code-Mixing. Cambridge: CUP.

Nyambura, N. G. (2015). Code-switching as a communication strategy in secondary schools: A case study of St. Francis girls' High School, Mang'u. Thesis retrieved from http://erepository.uonbi.ac.ke/bitstream/handle/11295/95001/Ngugi_Code-switching

Oxford, R. (2003). Language learning strategies: An overview. Proceedings of GALA 2003 (Generative Approaches to Language Acquisition) Volume 1.

Rubin, J., \& Thompson, I. (1994) How to be a more successful language learner. Boston, MA: Heinle $\&$ Heinle Publishers

Schmidt, A. (2014). Between the languages: Code-switching in bilingual communication. Hamburg: Anchor Academic Publishing.

Tarone, E. (1981). Some Thoughts on the Notion of Communication Strategy.TESOL Quarterly 15, 285-295. https://doi.org/10.2307/3586754

Tarone, E. (1981). Some thoughts on the notion of communication strategy. TESOL Quarterly, 15 (3), 285-295. https://doi.org/10.2307/3586754

Thomas, D. R. (2006). A General Inductive Approach for Analyzing Qualitative Evaluation Data. American Journal of Evaluation 27(2), 237-247. https://doi.org/10.1177/1098214005283748

Selinker, L. (1997). Rediscovering interlanguage. London: Longman. 